\title{
COMPUTER COMMUNITY SERVICE KARANG TARUNA RW 06 AND RW 12 PASIRMULYA VILLAGE, BANDUNG
}

\author{
Sani Muhammad Isa ${ }^{1 *}$, Maryani ${ }^{1}$, Hendro Nindito ${ }^{1}$ \\ ${ }^{1}$ Information Systems Department, School of Information Systems, Bina Nusantara University \\ Jakarta, Indonesia 11480 \\ *sisa@binus.edu
}

\begin{abstract}
Pasirmulya Village, located in Bandung, is a village that has several potentials such as coffee, handicrafts, and tourism. But there are still obstacles in marketing products from the village, especially handicraft products. The marketing techniques currently used are still not optimal, so the potential of handicraft products has not been optimally exploited. Online sales media proved to be very effective in marketing products to consumers, given the ease offered and not knowing distance and time. To start online sales, adequate knowledge is needed in terms of operating a computer and utilizing the internet network. At this moment, most of the participants were high school graduates, the rest were junior high school graduates and about half of the participants are 15-20 years old. This community service activity aims to provide knowledge in operating computers, creating documents with word processing software, processing data with worksheet software, and utilizing the internet that supports marketing activities. The target of this training is the members of Karang Taruna RW 06 and RW 12 in Pasirmulya. It is expected that after the implementation of this training the members of Karang Taruna can pass on the knowledge they have gained to other members of the village community.
\end{abstract}

Keywords: Pasirmulya, computer training, online sales

\section{INTRODUCTION}

Administratively the village of Pasirmulya belongs to the Banjaran district, Bandung, West Java. Pasirmulya village consists of 3 hamlets which are divided into 4 RWs and 69 RTs. The total area of the village is $442 \mathrm{Ha}$ [1]. In the west of the village is bordered by Sindangpanon Village, Banjaran Subdistrict, bordering Pasirhuni Village in Pengalengan Subdistrict in the east, Neglasari Village Banjaran Subdistrict in the south, and Mekarjaya Village Banjaran District in the north. The characteristics of the village which is directly adjacent to the Puntang Mountain Tourism Area is characterized by rural areas.

Pasirmulya village has great potential in plantation products, especially coffee. Coffee products from farmers in Pasirmulya village who have won the Special Coffe Association of America (SCAA) in Atlanta in the United States in 2016 received the highest score of 86.25 with an auction price of 55 USD per kg. The coffee is planted on the slopes of Mount Puntang which is very close to the village of Pasirmulya. Currently there are 400 hectares of coffee land around the Mount Puntang area. About 150 coffee farmers from the villages around Gunung Puntang plant, care for, and harvest Arabica coffee beans. The land area is still unable to meet the current market demand. In addition to coffee products, there are other commodities from the village of Pasirmulya which currently have shown their potential namely handicraft products such as shoes and bags. 


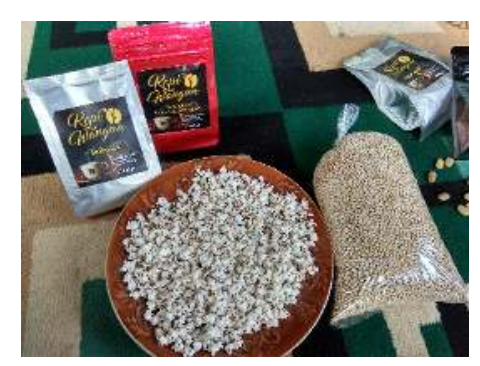

a. Coffee

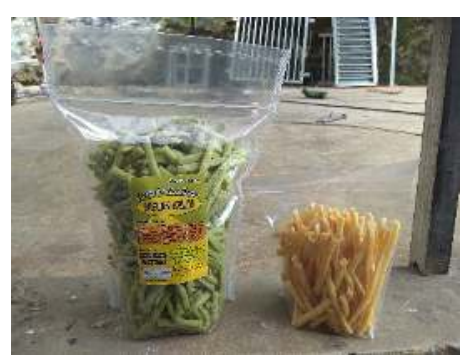

b. Snacks

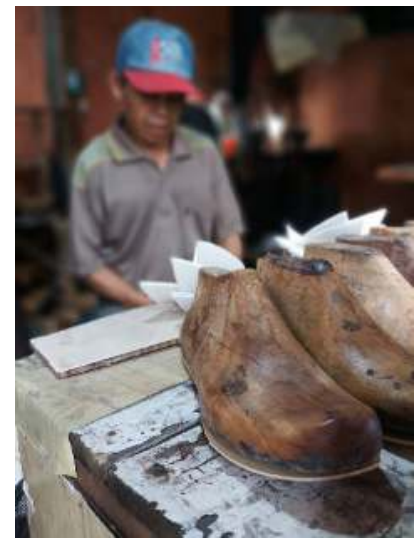

c. Shoes

Figure 1. Products from the village of Pasirmulya

Based on 2014 data, the total population of the village is 5,725 people, consisting of 3,993 adults, 2,753 men and 2,972 women. Poverty is an indicator of the inability to get enough food, because of the low purchasing power or inability to meet basic needs, such as food, clothing, housing, education, and others. Data from the 2016-2020 strategic plan report from the Food Security Agency and Bandung Regency Extension Implementers shows that Pasirmulya village is still one of the 5 villages in Banjaran sub-district that receive development priorities seen from poverty indicators. Statistical data in 2012 states that the number of poor families is still quite large, namely 548 households (KK) or about $35 \%$ of all households in the pasirmulya village. In 2017, the village of Pasirmulya received the BKM Award for its efforts and work to create a healthy, clean and tidy environment. Thanks to the KOTAKU program, which together with the community-based settlement (PLPBK) and community management and the support of the local government and central government, the village has changed from a slum and lagging behind the development of its area into a comfortable and neat village [2].

One of the things that can be done to overcome the problem of poverty is the utilization of the potential of Pasirmulya village which can support the improvement of the socio-economic capacity of the community. The potential that until now has not been optimally worked on is handicraft products. Products such as shoes and bags from Pasirmulya village have the potential to be marketed to various regions in Indonesia

A good product will not produce a good level of sales if it doesn't get the right market. The right marketing techniques can optimize the potential of a product so that it can produce a good level of sales. The main problem faced by shoe and bag craftsmen in Pasirmulya village is in terms of marketing. The method that has been used in marketing handicraft products from the village is through word of mouth. This marketing method is still not effective to achieve a good level of sales. The production capacity of shoe and bag craftsmen in Pasirmulya village is still greater than the orders from consumers. For this reason, a good marketing strategy is needed so that the potential sales of handicraft products from Pasirmulya village can be optimized.

Rapid developments in technology have changed us in doing many things, including in terms of buying and selling. Many argue that the large number of closed retailers in the last two years is due to the increasing sales through online media. Consumers now prefer to buy products from online stores 
because of the convenience offered by online sales systems. Consumers can find out the details of the product they will buy from information on the online store or from the product manufacturer's internet site. Consumers can also compare prices from different shops, so they can get the best price from the product they want to buy. Another thing that is taken into consideration is that consumers do not need to move from their place to get the product they want, even now there are many online stores that provide delivery services that can deliver ordered products on the same day. Of course this is very helpful especially for buyers who are in a big city like Jakarta which is almost never empty of traffic.

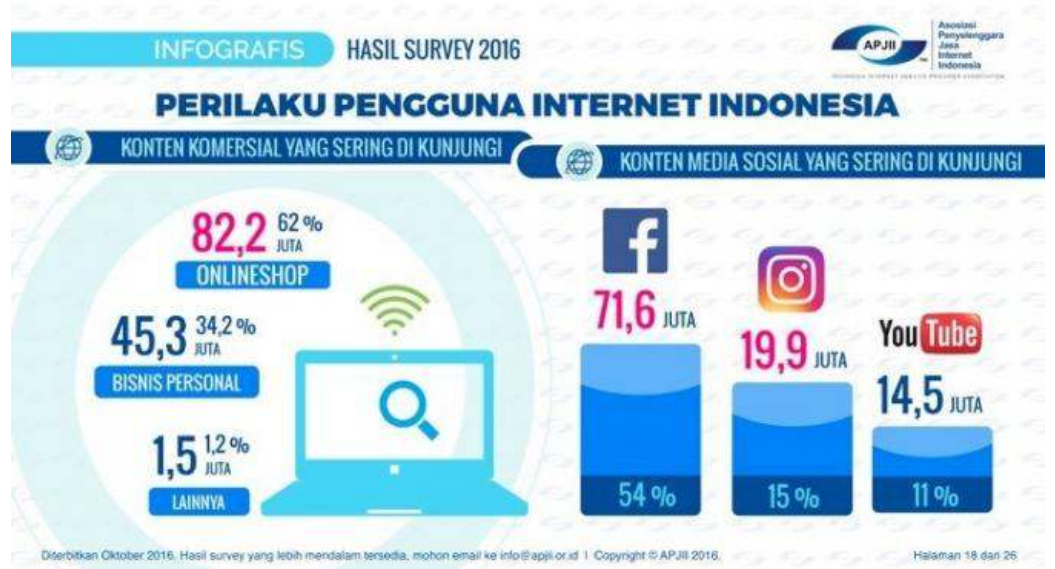

Figure 2. Results of the 2016 APJII survey about the behavior of internet users in Indonesia

The trend that is currently developing in the field of online sales is the use of social media as a tool to market products. The potential for online sales through social media is huge, given the huge social media users in Indonesia. The results of a survey conducted by the Indonesian Internet Service Providers Association (APJII) in 2016 as shown in Figure above [3], shows that the most frequently visited commercial sites are online stores ( 82.2 million or $82.2 \%$ ), personal businesses ( 45.3 million or $34.2 \%$, and the three social media that are frequently visited are Facebook (71.6 million), Instagram (19.9 million), and YouTube (14.5 million). Looking at these data, the use of social media to market products has enormous potential in Indonesia. online is not requiring sophisticated tools to do it, it can even be done using only cellphones, but that does not mean that making online sales by utilizing is easy to do, it requires knowledge of marketing techniques, utilizing social media features that support, and understanding of products will be sold and prospective customers.

Based on data from the Ministry of Communication and Information, in 2018 active users of cellular phones will reach 100 million. This number puts Indonesia in fourth place from countries with the largest population of cell phone users after China, India, and the United States. In 2016, the number of online sales transactions on computer devices was still higher than cellular phones (21.4 million vs. 12.8 million transactions), but this year the number of online sales transactions via cellular phones will beat transactions originating from computer devices [4]. iPrice Insights predicts that by 2018 the number of online sales transactions via mobile devices has surpassed transactions originating from computer devices as illustrated in Figure below [5] 


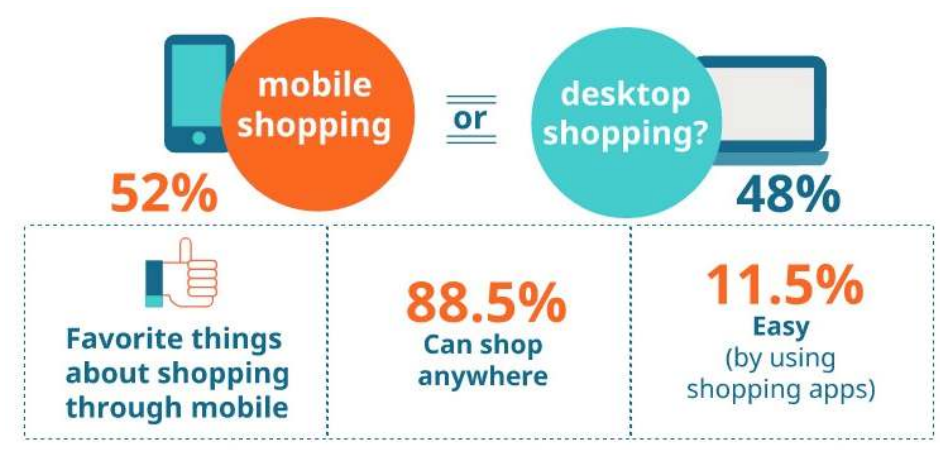

Figure 3. Prediction comparison of online sales transactions from cell phones compared to computer devices

Shoe and bag craftsmen in Pasirmulya can use social media to market their products online. It is hoped that the use of online-based marketing techniques can increase the reach and effectiveness of the sale of their products. Of course the biggest hope is the increase in sales turnover which will increase the socio-economic level of the craftsmen in Pasirmulya village, so that it can reduce the poverty rate which is still quite high. Even though the people in Pasirmulya village are very familiar with mobile devices and the use of social media, they do not yet have the required knowledge to start these activities. The ability to operate computers is a basic skill that needs to be mastered by the Pasirmulya village community. For this reason, a training is needed that can equip them with knowledge that can later support the marketing of handicraft products.

\section{Problems}

In relation to the socio-economic conditions of the Pasirmulya village community, the root of the problem is that the village has great potential in terms of tourism and plantation and handicraft products, but the marketing is not optimal so the information about the potential of the village is still limited. In addition, there is still limited knowledge of craftsmen regarding marketing techniques and technology utilization that can support the marketing of their handicraft products. The educational background of Pasirmulya villagers is still an obstacle in understanding the use of computer technology that can support the marketing of their products

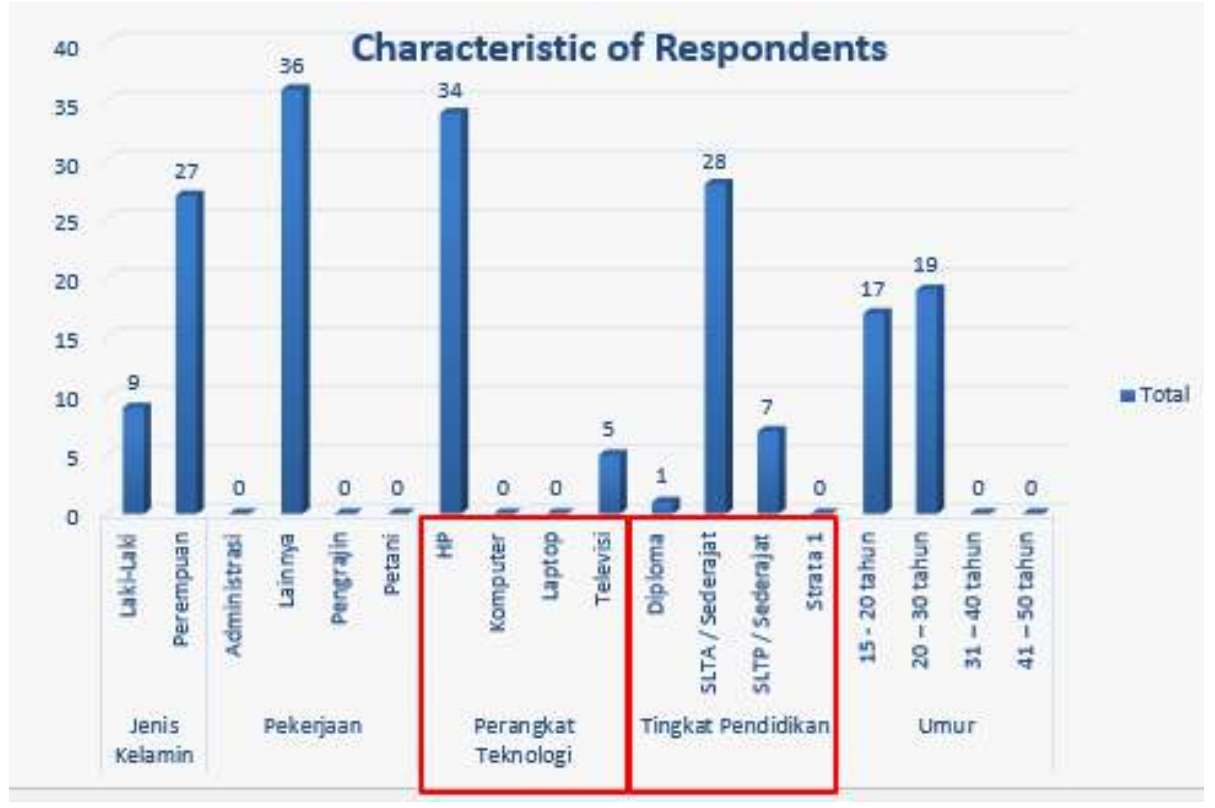

Figure 5. Respondent Characteristic 
In line with the problems faced by craftsmen in Pasirmulya village in marketing their handicraft products, the general purpose of Community Service is to provide knowledge, especially in operating a computer that can later support the marketing of Pasirmulya village handicraft products in order to improve the standard of living of its citizens. While the specific purpose of this Community Service activity is to empower youth cadets by providing computer training consisting of basic knowledge of operating computers, creating documents using word processing software (word processors), processing data using spreadsheet software, and utilizing resources from the internet to support positive activities. After the training is completed, it is expected that the members of Karang Taruna can then pass on the knowledge that has been obtained to other community members. Thus the members of Karang Taruna will play a role as pioneers in improving the knowledge of Pasirmulya villagers, especially in the operation of computers that can support the marketing of handicraft products from the village.

In accordance with the problems that have been explained, the solution that we propose to overcome the problems in Pasirmulya village is to provide training for members of Karang Taruna especially in the operation of computers which can later be useful to support the marketing of handicraft products from the village. Training topics include the use of basic computers using the Microsoft Windows operating system, creating documents using word processing software, processing data using worksheet software, and utilizing resources from the internet to support positive activities.

\section{METHOD}

Comunity services activities in Pasirmulya village will be carried out in three main stages, namely needs analysis, training, and evaluation of training results. The target of this activity is the members of the village Karang Taruna, with the hope that they can pass on the knowledge they have gained to other members of the village community. Thus they have participated in pioneering activities to increase knowledge of rural communities, especially in the mastery of computers. The entire series of these activities are planned to be completed within 8 months as shown in table 2 . In the first month the activities will be focused on needs analysis and material mapping. In the second month until the eighth month is the implementation of training activities and evaluation of training results. Whereas in the seventh month will be focused on the activities of making reports on Comunity services activities.

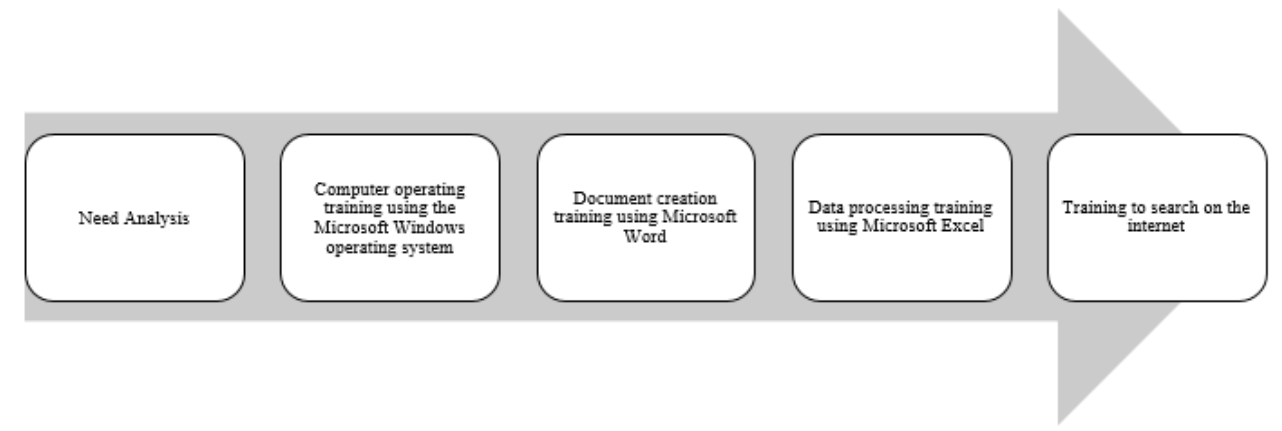

Figure 6. Methodology

\section{RESULT AND DISCUSSION}

Given the limited level of education of prospective trainees, the training method that will be used later needs to be adjusted to these conditions. Training activities are planned in the form of explanations of material, tutorials, case studies and discussions. Explanation of the material will be carried out by displaying Microsoft PowerPoint slides on the screen using an LCD projector. All participants will also receive a hard copy version of each material presented to optimize the learning process. The tutorial activity will provide a step-by-step explanation by giving examples of each material that will be discussed on each topic. This tutorial method is expected to facilitate participants in practicing the material delivered by the instructor. In order for the participants to get a clearer picture of the application of knowledge they have obtained in real activities, some simple case studies will be given that simulate the use of computers in this case Microsoft Word and Excel, especially in activities 
that support product marketing. Each training session will be closed with a discussion that aims to provide opportunities for participants to ask questions and discuss further with the instructor or other participants so that they can better understand the material that has been delivered.

The trainees will use one computer unit available at the Village Hall for each group consisting of 3 people. The grouping of participants needs to be done considering the limitations of the number of computers available at the Village Hall. Regarding this, each training session will be limited according to the number of computers available. Currently there are 5 computers available at the Village Hall which can be used to support this training activity, thus the number of participants that can be accommodated in each training session is 15 people. The number of training sessions that will be implemented is adjusted to the number of participants who are interested in participating in the training. As shown in Table 3, the training will be carried out in 3 sessions per day with a duration of 1.5 hours per session. The first session was held at $9.30-12.00$, the second session at 12:00 - 13:30, and the third session at $14.00-15.30$. Each instructor will deliver the material for one full day.

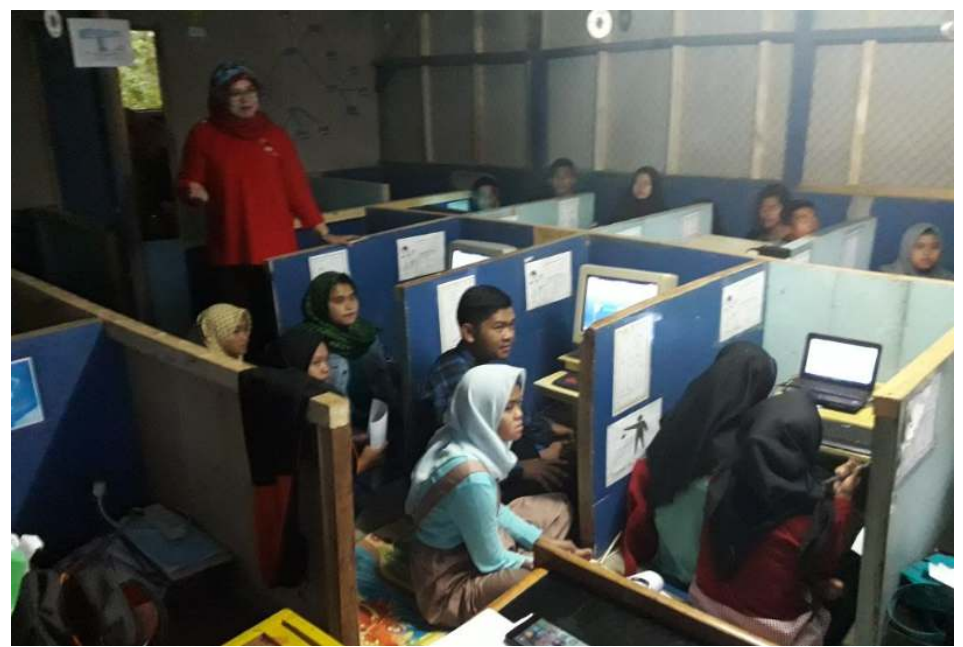

Figure 7. Training Implementation

\section{CONCLUSION}

Participants have the potential to become pioneers in Pasirmulya village in encouraging the application of computers in various productive activities there because they have an adequate level of education and are still young :

- $78 \%$ of participants were high school graduates, the rest were junior high school graduates

- $47 \%$ of participants are 15-20 years old, the rest are between 20-30 years old

Some participants have the ability to operate computers well so that they can be a place to ask their colleagues. Approximately $35 \%$ of participants already have sufficient skills in operating word processing, worksheets, presentations, and internet technology

\section{REFERENCES}

K. Setda, "BKM Warga Mulya Banjaran Raih Terbaik Kedua Tingkat Nasional," Pemerintah Kabupaten Bandung, 2017. [Online]. Available: http://www.bandungkab.go.id/arsip/bkmwarga-mulya-banjaran-raih-terbaik-kedua-tingkat-nasional. [Accessed: 22-Aug-2018].

Penetrasi Pengguna Internet Indonesia," Asosiasi Penyelenggara Jasa Internet Indonesia. (n.d.), 2016. [Online]. Available: https://apjii.or.id/content/read/39/264/Survei-Internet-APJII-2016. [Accessed: 22-Aug-2018]. 
Rahmayani, I. (2017). Indonesia Raksasa Teknologi Digital Asia. Melalui: https://www. kominfo. go. id/content/detail/6095/Indonesia-raksasa-teknologi-Digital-asia/0/sorotan_media.

Tim iPrice, "Laporan Kuartal I 2018 Industri E-commerce Indonesia,” 2018. [Online]. Available: https://iprice.co.id/trend/insights/laporan-kuartal-i-2018-industri-e-commerce-indonesia/. [Accessed: 22-Aug-2018].

Yopy, M., \& Sitinjak, M. F. (2018, March). Developing performance excellence guidance for rural tourism (case study: wangun lestari village, Bandung, West Java, Indonesia). In IOP Conference Series: Earth and Environmental Science (Vol. 126, No. 1, p. 012064). IOP Publishing. 